OBETS. Revista de Ciencias Sociales

Vol. 11, n. ${ }^{\circ} 1,2016$, pp. 255-285

ISSN: $1989-1385$

DOI: 10.14198/OBETS2016.11.1.10

\title{
LA REDUCCIÓN ENUNCIATIVA: PODEMOS Y LA CONSTRICCIÓN DE LA VOZ DE LA MULTITUD ${ }^{1}$ THE ENUNCIATIVE REDUCTION: PODEMOS AND THE CONSTRICTION OF THE MULTITUDINOUS VOICE
}

\author{
José Antonio Palao Errando \\ Universitat Jaume I \\ Departament de Ciències de la Comunicació \\ Facultat de Ciències Humanes i Socials \\ Castellón de la Plana, España \\ errando@uji.es
}

\begin{abstract}
Resumen
La irrupción política de Podemos en el panorama mediático y electoral español ha supuesto no sólo una revolución política sino también comunicativa. El 15M significó la crisis definitiva de la hegemonía indiscutible del Modelo Difusión en política, como ya se había verificado en otros espacios de comunicación social. Con su "no nos representan", el 15M fue ante todo un proceso de disolución enunciativa. Tras él Podemos es el único caso de un experimento de hibridación integral del Modelo Difusión y el Modelo Reticular, intentando propiciar su sinergia. El desembarco de Pablo Iglesias en la televisión resulta crucial, pues se trata de un intento de abrochar la enunciación mediático-electoral con la enunciación popular-reticular.

Palabras clave : Podemos; Pablo Iglesias; Comunicación Política; Ernesto Laclau; Populismo; Televisión; Agenda Setting.
\end{abstract}

${ }^{1}$ Este texto se ha realizado con la ayuda de los proyectos de investigación La crisis de lo real: la representación documental e informativa en el entorno de la crisis financiera global, dirigido por el Dr. José Javier Marzal Felici y financiado por el Plan de promoción de la investigación de la Universitat Jaume I para el período 2015-2017 (PI: 1A2024-05), y PI MICINN 2015-2017, El sistema de investigación en España sobre prácticas sociales de comunicación. Mapa de proyectos, grupos, líneas, objetos de estudio y métodos, referencia CSO201347933-C4-4-P, código 14I275.01/1. 


\begin{abstract}
The political emergence of Podemos in the Spanish media and electoral landscape has meant not only a political but also communicative revolution. $15 \mathrm{M}$ meant the definitive crisis of the undisputed hegemony of Broadcasting Model in politics, as already verified in other areas of social communication. With its statement "they don't represent us," 15M movement was above all a process of enunciative dissolution. After it, Podemos is the only case of a comprehensive hybridization experiment between Broadcasting Model and Net-like Model, trying to promote their synergy. The landing of Pablo Iglesias on television is crucial, because it is an attempt to fasten the media-electoral statement with the popular-reticular enunciation.
\end{abstract}

Keywords: Podemos; Pablo Iglesias; Political Communication; Ernesto Laclau; Populism; Television; Agenda Setting.

\title{
Extended abstract
}

The political breakthrough of Podemos in the Spanish media and electoral landscape has brought not only a political but also a communicative revolution. 15M movement meant the definitive crisis of the undisputed hegemony of the Broadcasting Model in politics, already verified in other areas of social communication. With its slogan "They don't represent us", 15M was primarily a process of enunciative dissolution. After 15M movement, Podemos is the only case of a comprehensive hybridization experiment between the Broadcasting and the Reticular communication Models, trying to promote their synergy. The landing of Pablo Iglesias on television is crucial, because it is an attempt to do up the media-election statement with the popular-reticular enunciation. As a consequence, Podemos is being built with the logic of an underground party in full media light.

Our purpose is to study the Podemos new communicative, semiotic and hermeneutic challenge, which has led it both to be considered a glaring media success and to be continually labelled as a populist party. To do this, we focus on the epistemological break conducted by Ernesto Laclau and Chantal Mouffe within Marxist Theory and we will try to narrow the discursive field set both by the reticular means that Podemos uses and the television coverage received by Pablo Iglesias in his transit from commentator to politician, with special attention to his staging, which reflects patterns of the radicaldemocratic populist leader (in the style of Latin American populist leaders) or the media liberal-parliamentary leader (typical of the North Western democracies), attending not just to a matter of audiences and other metrical patterns, but to the structure of the communication system and the enunciative position as well.

To investigate this specific proposal for joint political discourse enunciation we can divide the analysis into two parts. First, we will conduct a review of media treatment of the figure of Pablo Iglesias, using tools that come from film analysis of television broadcasts, with a particular emphasis on its enunciative articulation. Therefore, what we advocate in our approach is a different way: we consider that both the people and the public opinion are 
operating as fictional constructs and, therefore, we can define the reader models for each enunciative mode (Foucault, 2002). In so far as in both models we can observe the traces of the subject of enunciation, the communication partners are understandable as two types of receptor model of political discourse. Populism should thus become an inchoate process that constituted the People (Laclau, 2006) as a media and discursive receptor.

Later, we will investigate the evolution of speech, collating key elements of Ernesto Laclau's analysis of political discourse, such as empty signifiers and floating signifiers, with the audiovisual analysis of the campaigns of several candidates to the regional and local elections held in 2015, in order to sift through the various discursive and communicative strategies that have been implemented in the hegemonic and counter-hegemonic dynamics in the Spanish field, in terms of political strategy and overflow.

We will close our analysis by exposing a curious phenomenon: although people can intervene electronically through Podemos.info Plaza can and, of course, have the feedback option through the Agora Voting platform, this means that the system has a propensity basis we might call tele-cratic (Stiegler, 2006). The Podemos promoter core members can reach easily a quick access to television channels, and many other members of the political staff can access to journals and newspaper, while the thesis which are oppose to them have these resources very limited. The conclusion is that, with the possibility of drawing up comprehensive lists for all positions of each organ, and selecting them with one click, the lists and thesis sponsored by Pablo Iglesias under the Claro que Podemos brand can earn a regular form of overwhelming success. The television viewers become tele-electors.

\section{INTRODUCCIÓN}

\subsection{La operación Laclau: hegemonía y populismo}

Como hemos afirmado en otra parte [(Laclau \& Mouffe, 1987)], entendemos las lógicas sociales como involucrando un sistema enrarecido de enunciaciones, es decir, un sistema de reglas que trazan un horizonte dentro del cual algunos objetos son representables mientras que otros están excluidos (Laclau, 2007: 150).

La operación epistemológica y teórica llevada a cabo por Ernesto Laclau y Chantal Mouffe (Laclau \& Mouffe, 1987) supuso una ruptura radical con el materialismo marxista ortodoxo y con todos sus fundamentos ontológicos, que consistían en la creencia en unas clases sociales objetivamente existentes y, por ende, en una inexorabilidad de las leyes de la Historia. Es, pues, una apuesta de radicalización democrática -es el término que ellos utilizan- que incorpora una preeminencia de lo político sobre lo económico y que coloca en el centro del análisis el concepto de hegemonía, aceptando de buen grado la contingencia de las operaciones políticas. Laclau parte de una conexión que transita desde el marxismo hacia la lingüística, el psicoanálisis y la filosofía del lengua- 
je contemporáneas para acabar postulando que "la sociedad no existe", es decir, no es un objeto de estudio estable y predefinido como querrían la economía y la sociología positivistas, de las que se nutre el neoliberalismo con sus estadísticas, sus encuestas y sus leyes del mercado. Pero tampoco está determinada por las leyes eternas de la relación entre las fuerzas productivas y la lucha de clases, como quedaba esperando el marxismo ortodoxo. No otra cosa está detrás de las luchas populares actuales en América Latina.

Por esta razón, una parte de la sociedad ha de convertirse en representante de la totalidad, del pueblo, a través de las batallas simbólicas y retóricas en un espacio de enfrentamiento democrático en el que las demandas sociales insatisfechas se articulan por un proceso de equivalencia que construye un nuevo antagonismo: lo que era una subordinación incuestionada, a través de estos desplazamientos de sentido, acaba viéndose como una opresión contra la que luchar. Es como consecuencia lógica de este giro epistemológico postmarxista que Laclau (2007) ha podido reivindicar posteriormente el término populismo. Laclau primero, y después Mouffe (Mouffe, 1999, 2007) o Zizek (Zizek \& Horvat, 2014), están haciendo ese trabajo de rescatar el populismo ${ }^{2}$ para la racionalidad política, reivindicando su uso por la izquierda.

Hemos de subrayar que en Laclau la construcción hegemónica dista de ser considerada una especie de técnica a disposición del consumidor, en cuyo caso equivaldría a una mercadotecnia, o a una fórmula publicitaria. Construir una hegemonía es un proceso complejo que no debe confundirse con algo así como la viralización, el posicionamiento de marca o la consecución de que una consigna se convierta en tendencia (en trending topic), por utilizar expresiones típicas del discurso publicitario. El proceso antagónico es un proceso de acción-reacción sin un resultado exactamente prefijado, y el mismo Laclau, si bien hablaba de lucha social, se distancia de la dialéctica clásica (hegeliana o marxista) que siempre resultaba en una utópica reconciliación final de toda la sociedad consigo misma.

Pero el terreno dentro del cual operaba el populismo era el de las equivalencias espontáneas. ¿Qué ocurre, sin embargo, si el pueblo es concebido como una entidad homogénea a priori postulada desde un centro de poder que, en lugar de ser el precipitado social de una interacción equivalencial de demandas democráticas, es percibido como el que determina una sustancia idéntica a toda demanda expresa? En ese caso, la división interna inherente a toda de-

${ }^{2}$ No es nuestro objetivo en este artículo una discusión politológica sobre los términos populismo y hegemonía en sus diversas concepciones, sino una contemplación de cómo su formulación por Ernesto Laclau ha influido directamente en las prácticas político-comunicativas de Podemos. 
manda democrática dentro de la cadena equivalencial se derrumba, el pueblo pierde sus diferenciaciones internas y es reducido a una unidad sustancial. El pueblo aún puede ser concebido como una fuerza radical opuesta al statu quo existente, pero ya no es más una plebe marginal: se ha abandonado la heterogeneidad esencial que está en la base de toda identidad populista y es ahora reemplazada por una unidad homogénea. Eso es lo que ocurrió en Turquía, y explica por qué el kemalismo pudo haber sido un discurso radical, de ruptura, pero nunca fue populista (Ernesto Laclau, 2007: 259).

\subsection{El Paradigma Informativo, el Modo Difusión y el Modo Reticular}

Hace años ya que venimos conjugando dos conceptos para intentar dar cuenta del nuevo paradigma mediático, ya no apaciblemente masivo: por un lado el concepto de paradigma, proveniente de la epistemología, y por otro el de modo de representación, que tomamos de la teoría fílmica. De este modo, hace ya unos cuantos años acuñamos el concepto de Paradigma Informativo (Palao, 2004 y 2009B) para dar cuenta de la episteme contemporánea, en la que rige la creencia de que todo conocimiento es susceptible de ser reducido a su cifrado informativo, es decir, de ser cuantificado y digitalizado. Ahora bien, cuando vimos establecerse la Web 2.0 (Palao, 2009B) y tuvimos que tomar la decisión teórica de proponer un cambio de episteme, nos dimos cuenta de que el cambio en la concepción del conocimiento y de su transmisión no era tan radical como para propugnar un cambio de paradigma, así que decidimos establecer una división interna en el Paradigma Informativo/Comunicativo y, echando mano de un término perfectamente legitimado en teoría fílmica, decidimos hablar de un desdoblamiento en dos Modos de Representación, puesto que no tiene sentido hablar de unos medios o canales en oposición a otros cuando lo que vemos continuamente es su convergencia (Jenkins, 2008), su intercambio de contenidos, su remediación (Bolter, Grusin, \& Grusin, 1999), su competencia, sus sinergias y colonizaciones. Multimedia, hipermedia, transmedia, cross-media son los adjetivos que llevan casi dos décadas acompañando a los medios digitales.

Evidentemente, las primeras industrias culturales masivas, desde la imprenta a la televisión, desarrollaron una forma de comunicación radial y unidireccional que implicaba un modo de representar acorde con sus fines y condiciones: el espectador, directa o indirectamente, estaba constituido en público pasivo y su representación (construcción y desarrollo de sus mociones y trayectos desiderativos) eran tomados a cargo por el sujeto de la enunciación, tomara éste el semblante del narrador omnisciente, del esquema cognitivo cámara, la mirada privilegiada del pintor o la retórica del líder político de un partido. El objetivo 
de este modo de representación es esencialmente difundir, llegar al máximo de un público que concibe como pasivo, bajo la forma del adoctrinamiento, la denuncia, la clarificación simbólica de lo real y la gestión plenipotenciaria de la posición del receptor, que siempre es inactivo discursivamente. Por eso lo llamamos, Modo Difusión.

La tecnología digital, sin embargo, ha propiciado las comunicaciones interactivas en línea y en tiempo real, lo que ha propiciado la no absoluta soberanía del emisor y la propagación de la información a través de nódulos que acaban constituyendo redes comunicativas, no solo cauces radiales, expansivos y unidireccionales. Por eso lo denominamos Modo Reticular. Lo que vimos, pues, es que el concepto de información y de comunicación sigue subyaciendo a ambos modelos sin que se haya producido una auténtica ruptura paradigmática. La mejor prueba es que es imposible encontrarse con una manifestación pura de uno de ellos, sino que lo que nos encontramos continuamente en los actos comunicativos concretos son hibridaciones de ambos. Un blog, o un usuario de Twitter o Facebook es un microdispositivo de difusión y la estructura de sus perfiles y páginas lleva el marchamo de este modo de representación. Un periódico tradicional o un programa de televisión ya no pueden estar en marcha sin contar con la retroalimentación automática de los contenidos que difunde a través de mensajes, foros y, por supuesto, redes sociales, lo cual se trasluce en la temporalidad de su emisión, en la composición del encuadre, etc., es decir, en sus maneras de representar, de poner en escena.

Utilizar este aparato conceptual es importante, pues, si tenemos en cuenta todas estas hibridaciones. No hay un solo medio que no conjugue en mayor o menor proporción características de ambos y además están siempre en relación de diálogo e interacción y no es nada útil oponer mass media a social media, como si fueran medios puros y estancos. Tampoco es conveniente en absoluto adjudicarles propiedades y potencialidades de forma apriorística. Como el Modo Reticular admite más voces, sería por esencia más libertario y democrático que el Modo Difusión. No olvidemos, por ejemplo, que la dinámica grupal tribal o de clan, puede ser incluso más fuerte que la de los medios tradicionales. Y que, a su vez, estos, en su implementación secuencial, han arbitrado modos de conciencia crítica y de atención al sentido, es decir, de incidir sobre lo real y su transformación, que los medios reticulares aún no han demostrado. De hecho, los métodos crítico-hermenéuticos nacen para los modelos institucionales burgueses, que se materializan en el patrón Obra/Texto, por mucho que lo hagan reaccionando contra él, sobre todo a partir de los modelos metodológicos nacidos de la semiótica y el estructuralismo. 


\subsection{El 15M, el paradigma Occupy y la crisis de la democracia representativa}

El 15M, no sólo fue el acontecimiento políticamente más relevante en España desde la Transición. También significó la crisis definitiva de la hegemonía indiscutible del Modelo Difusión en política, como ya se había verificado en otros espacios de comunicación social. Con su "No nos representan" (Tormey, 2015b), el 15M fue ante todo un proceso de disolución enunciativa. Recordemos, también, que no fue un fenómeno pintoresco e idiosincrásico, sino que se enmarcó en un flujo global que implicaba al movimiento Occupy o a las primaveras árabes. El caso es que el 15M puso en primer plano la cuestión del uso estratégico y político de los medios ubicuos (Dovey \& Fleuriot, 2011; Ekman \& Fuller, 2013) al servicio de intereses que no eran los del puro marketing político, como había supuesto el caso de las campañas de Obama, que esencialmente no fueron otra cosa que un nuevo desembarco del Modelo Difusión en los canales reticulares digitales, al estilo de las que ya perpetraron las industrias culturales (y las otras) en la Web 1.0 (Palao Errando, 2004: 345 y ss.). Y ello conllevaba, así mismo, la sospecha hacia cualquier imagen de liderazgo, porque la figura que se pudiera tener del líder en las sociedades europeas, o bien era la del líder empresarial neoliberal o la del líder político profesionalizado y mediáticamente hipervisible, y ninguna de ambas se avenía en absoluto al espíritu del 15M.

El 15M surgió, pues, como un movimiento sociopolítico radical: toma de la calle, método asambleario y renuncia premeditada a ser condensado y confinado en la figura de un líder mediático. Por ello, su principal eslogan, "No nos representan", no era una alusión a una formación política, ni a una tendencia ideológica, sino una protesta contra el sistema representativo propiamente dicho, en tanto que éste impedía a la ciudadanía el acceso a la participación política (Tormey, 2015a, 2015b). El 15M, pues, no tuvo nunca una intención ni una proyección electoral. Aconteció justo en un momento en el que acaba un ciclo electoral de izquierda parlamentaria y en el que todas las encuestas vaticinaban una victoria irrefutable de la derecha en el siguiente ciclo de comicios. No se trataba de ir contra esta marea neoliberal en su terreno parlamentario, sino de plantear un terreno de lucha política participativa alternativo a la arena parlamentaria, cuyos engranajes estaban totalmente dominados por el emporio financiero y mediático a través del sistema bipartidista. Por eso, tal vez, ciertas voces del sistema empezaron a reputar el 15M como un fracaso y le inocularon el ansia de éxito sustanciada en la imagen de una victoria electoral. El 15M era simplemente emocional (Verdú, 2001) y carecía de una coherencia programática y política, y ahí se agotaban sus posibilidades. 
Ahora bien, este semblante de incoherencia, creemos, no descalificaba al $15 \mathrm{M}$ si tenemos en cuenta el campo de complejidad enunciativa en el que se produce. Más bien, hubiera podido ser el epifenómeno y el germen de una subversión radical de la comunicación concebida como campo único de enunciación política en tiempos mediático-liberales, que es el núcleo estructural de toda la sensación de impotencia en la que la ciudadanía se hallaba encallada desde hacía décadas en las sociedades parlamentarias liberales y que le había impedido constituirse como sujeto popular. Este cuestionamiento es, pues, condición necesaria de todo populismo emancipador, porque impide el abroche, el cierre imaginario, tanto bajo la imagen monolítica de un líder manipulador como bajo la de un sentido garantizado por un sustrato ontológico que considere el proceso social como obediente a unas leyes inmanentes de la historia. Es decir, la disolución del sentido, aún más en su faz domésticamente ilustrada, podríamos afirmar que es requisito indispensable para la conquista del espacio común y para poder construir una contra-hegemonía proactiva.

Como vemos, remitiendo a las categorías de Laclau -y cotejándolas con las tradicionales de la sociología crítica-, lo que se había consumado aquí era una ruptura enunciativa clave. Las nociones clásicas de la participación ciudadana como "opinión púbica" o "esfera pública" (Alejandro, 2013; Habermas, 1981; McCombs, 2006) quedaban dislocadas y aparecía una especie de "anarquía hermenéutica" (Vattimo \& Zabala, 2012), que tenía su principal plasmación en la toma de las plazas por la multitud, en un ejemplo de ejecución virtuosa colectiva (Virno, 2003). Pero, y esto era lo más relevante desde un punto de vista comunicativo y virtual, en una impostación de lo que hemos llamado Modelo Reticular frente al broadcasting comunicativo o Modelo Difusión (Palao Errando, 2009). Ello supuso un abordaje extenso de las diversas formas de ciberactivismo por los especialistas (Micó \& Casero-Ripollés, 2013; Quodlibetat et al., 2012; Sádaba, 2012; Tascón \& Quintana, 2012; Toret, 2014; Toret et al., 2013; Morell, 2012). Probablemente la idea de democracia monitorizada (Feenstra \& Casero-Ripollés, 2014; Feenstra, 2012) sea la que mejor describe, dentro de un paradigma reformista y ciudadanista, esa idea de una nueva democracia en el medio digital (Casero-Ripollés, 2014; Subirats, 2011) que tiene como buque insignia el affaire Wikleaks: las fuerzas que tradicionalmente controlaban las voces en los regímenes liberal-parlamentarios dejaban también de decidir monopolísticamente los silencios.

El caso es que, independientemente de que el proceso haya afectado a todas las opciones partidarias y las haya obligado a recolocarse en el panorama digital, hay tres modelos que intentaron responder específicamente a la demanda del $15 \mathrm{M}$ articulando propuestas electorales que no obedecieran al patrón clásico, 
que habría dejado de ser representativo de la ciudadanía. Las Candidatures d'Unitat Popular en Cataluña optaron por un modelo de implantación social y asambleario, mientras que el Partido X estableció un sistema de predominancia digital y telemática. Lo que resulta evidente es la fe ciudadanista de estas opciones, que creen en la existencia objetiva de la sociedad, en la consistencia ontológica de la "esfera pública". Podemos ha supuesto una opción distinta. Al no creer en su existencia plena, lo social puede ser siempre refundado creando un nuevo antagonismo.

\section{METODOLOGÍA}

\subsection{Análisis fílmico y visual}

Es sobre esta base conceptual y teórica como hay que entender el fenómeno de la irrupción de Podemos en el panorama mediático y electoral español, que ha supuesto no solo una transformación del panorama político, sino también del comunicativo. Nuestro propósito es aportar algunos elementos básicos para el estudio del nuevo reto comunicativo, semiótico y hermenéutico que implica Podemos y que le ha llevado tanto a un evidente éxito mediático como a ser continuamente motejado de populista. Por consiguiente, partiendo de la ruptura epistemológica llevada a cabo por Ernesto Laclau y Chantal Mouffe en el seno del marxismo, intentaremos acotar el campo de acción discursiva de Podemos y su implementación de los principios del populismo laclauiano. Una buena fórmula para acometer esta tarea es el análisis del tratamiento televisivo que ha recibido Pablo Iglesias en su tránsito desde su posición de tertuliano a la de político en activo, con especial atención a los patrones de puesta en escena del líder populista radical-democrático (al estilo de los líderes populistas latinoamericanos) o bien al líder mediático liberal-parlamentario (propio de las democracias noroccidentales) atendiendo no solo a una cuestión de audiencias y otros patrones métricos, sino de estructura del sistema comunicativo y de posición enunciativa.

Para indagar en esta propuesta específica de articulación enunciativa del discurso político que implementa Podemos dividiremos el análisis en dos partes. Primero, vamos a comenzar realizando un examen del tratamiento mediático de la figura de Pablo Iglesias utilizando herramientas que provienen del análisis fílmico de las emisiones televisivas y haciendo especial hincapié en su articulación enunciativa. Por consiguiente, lo que vamos a propugnar en nuestro enfoque es un abordaje distinto. Por ello, vamos a considerar que tanto el "pueblo" como la "opinión pública" son constructos ficcionales operativos, y por lo tanto los Podemos definir a partir de los modelos de enunciatario per- 
geñados por cada modalidad enunciativa (Foucault, 2002). En tanto ambas modelizan al receptor comunicativo desde las marcas que el sujeto de la enunciación deja en el discurso, son abordables como dos tipos de receptor modelo del discurso político. El populismo debería convertirse así en un proceso incoativo que constituyera al Pueblo (Laclau, 2006) como enunciatario mediático y discursivo.

Posteriormente, para investigar esta evolución del discurso de Podemos, cotejaremos elementos clave del análisis del discurso político de Ernesto Laclau, como son los significantes vacíos y los significantes flotantes, con el análisis audiovisual de varios spots de las campañas de diversas candidaturas a las Elecciones Autonómicas y Municipales de 2015, con el fin de cernir las diversas estrategias discursivas y comunicativas que se han puesto en marcha en la dinámica hegemónica y contra-hegemónica en el ámbito español en función de la estrategia de desbordamiento político propugnada por Podemos.

\subsection{El líder político mediático y el líder populista}

Como hemos afirmado, el lugar desde el que se enuncia modeliza el lugar de la recepción y modeliza el canal: si se habla como líder político mediático se hace en dirección a la opinión pública en el seno de la esfera pública. Esta opinión pública queda definitivamente emplazada como un sujeto pasivo e irresponsable (nadie responsabiliza a un electorado por las decisiones de los gobernantes que votaron). Si se habla como líder popular, el enunciatario queda emplazado en el lugar del pueblo, no de la opinión pública. Nos hemos de plantear, pues, la cuestión de si la representación performativa de Pablo Iglesias obedece al modelo de un líder populista o de un líder mediático y la única forma de hacerlo, desde el punto de vista de la teoría del discurso, es ver su diferencia y su posicionamiento en el seno de los modelos de representación mediática. Podríamos decir que hay dos grandes modelos de representación del líder político en las sociedades del siglo XXI. Por un lado, el líder mediático noroccidental, propio de los sistemas liberales parlamentarios en economías capitalistas avanzadas (evidentemente, los países de la UE y de América del Norte) en las que los medios de comunicación ofician de cuarto poder (V. Sampedro, 2014) de modo prácticamente institucional y la estructura político-mediática es formalmente bipartidista. Por otro, el líder populista radical democrático, que tiene por el momento su máxima expresión en diferentes países de América Latina.

Debemos, pues, siquiera sea someramente, caracterizar escénicamente la modulación enunciativa que constituyen ambos paradigmas a través de su materialidad, esto es, a través de su transmisión y puesta en escena. Veamos. El 
líder político (por simplificar) europeo jamás se dirige a su receptor-modelo (target comunicativo o público objetivo, dirían los publicitarios) directamente, sino a través de una función marco (intradiegética, en el interior de la representación) sustanciada en la prensa. Por eso, jamás mira al centro axial de la cámara, cosa que se consideraría una provocación o un gesto de mal gusto, en perfecta sintonía con la preceptiva actoral hollywoodense. Es decir, jamás habla a un pueblo sino a una sociedad y la emplaza como enunciatario en su papel de opinión pública/electorado. Por ello, su escenografía connatural es la rueda de prensa. De este modo, el líder político europeo se configura como un actor en un entorno de semblante pluralista y el público intradiegético hace la función de marco enunciativo. Pensemos también en otro ejemplo de líder en el capitalismo avanzado, el gurú publicitario (siempre dispuesto a las revelaciones que van a cambiar nuestra percepción del mundo), de Steve Jobs a Al Gore, pasando por otros activistas o "concienciadores", que venden una idea, un concepto, un intangible. La escenografía es siempre la misma: de pie frente a una sala oscura con un auditorio rendido. Y el público objetivo, los fans que van a ver el vídeo como un viral en las redes sociales. Fijémonos, por comparación, que el líder político liberal, incluso en un mitin, nunca habla a una sala oscura. Y nunca al espectador extradiegético, el que mira a la pantalla, que es su verdadero público objetivo.

Veamos pues en qué se diferencia la puesta en escena populista de la escena político-mediática parlamentaria noroccidental y en qué reside buena parte de su carácter escandaloso (demagógico, incoherente, vulgar, etc.) para el establishment europeo. Si el espacio natural del líder liberal es la rueda de prensa (y subsidiariamente el mitin), el del líder populista es el discurso (en el sentido restringido de la oratoria clásica: alocución ante un auditorio). El líder populista democrático, socialista del siglo XXI, mira directamente a la cámara. Y eso es intolerable para el espectador televisivo estándar en las democracias noroccidentales, si está pidiendo identificación agónica (Mouffe, 2014) o adhesión. Por tanto, para actores, tertulianos, políticos, concursantes y cualquiera que no sea un portavoz directo e imparcial del constructo semiótico llamado "realidad objetiva", el precepto sigue perfectamente en vigor. Los únicos que pueden mirar a cámara en la TV son los profesionales orgánicamente vinculados al staff de un ente difusor (por poner un fácil ejemplo: el presentador sí; el tertuliano deportivo o político, no) o los jefes de Estado en estricto cumplimiento de su función metapolítica, no partidista, sino representado a la integridad del Estado. Si al final de un debate electoral, los candidatos pueden dirigirse directamente a la audiencia es porque han sido protocolariamente invitados por el moderador institucional del debate. 
Probablemente, fue Hugo Chávez con su Aló Presidente (Buen Abad Domínguez, 2012; Elórtegui Gómez, 2013) el primero que rompió esta regla homeostática del principio del placer mediático-visual y se propuso como interlocutor directo de la audiencia sin renunciar a su parcialidad (a ser representante de partido) política. El líder populista emplaza a su enunciatario no como opinión-electorado pasivo e irresponsable, sino como pueblo y le demanda una escucha activa. A una sensibilidad liberal le tiene que molestar: se está metiendo en su vida privada. Por este motivo, la televisión en el siglo XXI ha aprendido a manipular pareciendo no entrometerse (vid. Palao, 2009: 365 y ss.).

\section{RESULTADOS Y DISCUSIÓN}

\subsection{La operación Pablo Iglesias y el abroche enunciativo}

\subsubsection{El asalto a los media}

Podemos es, pues, el único caso tras el 15M de un experimento de hibridación integral del Modelo Difusión y el Modelo Reticular, intentando propiciar su sinergia. En efecto, Pablo Iglesias desembarcó en la televisión difusión por invitación de la llamada "TDT Party" ${ }^{3}$ que lo presentó como representante del 15M. El gesto, visto con perspectiva a día de hoy, y teniendo abundantes fuentes recientes para saber que estaba perfectamente calculado, política y tácticamente (Domínguez \& Giménez, 2014; Riobóo, 2014; Rivero, 2014), resulta crucial y muy significativo, pues se trata de un intento de abrochar la enunciación mediático-electoral con la enunciación popular-reticular. $\mathrm{O}$, si se prefiere, con la enunciación virtuosa y multitudinaria del general inetelect (Virno, 2003). Recordemos que el 15M había sido simultáneo a una victoria aplastante de la derecha en todos los comicios habidos en 2011. Es decir, la calle y en buena medida las redes se habían convertido en el espacio enunciativo de los "antisistema", de los que cuestionaban el statu quo representativo, mientras que los medios del broadcasting (radio, mucha prensa, televisiones autonómicas [Marzal Felici, Izquierdo Castillo \& Casero-Ripollés, 2015; Marzal Felici, 2015] y privadas digitales) se habían convertido en un espacio ganado por la derecha. La grieta entre el sistema político, el mediático y el representativo estaba servida. Después, la historia es de todos conocida: Pablo Iglesias consigue notoriedad y pasa en breve tiempo de una televisión de alcance muy reducido como Intereconomía a ganarse un lugar de referencia en las tertulias

\footnotetext{
${ }^{3}$ Se conoce popularmente con este nombre a diversas cadenas surgidas con la proliferación de las licencias para la Televisión Digital Terrestre, de ideología manifiestamente conservadora.
} 
políticas de las televisiones generalistas y de ahí, cual territorio conquistado, da el salto al terreno electoral.

Visto esto, es la propia reivindicación política del populismo la que lleva a creer que puede haber un líder que empodere al pueblo, no que lo encarrile hacia el voto útil bajo una especie de realpolitik, como el ejecutivo empresarial o el gurú publicitario -los ejemplos más evidentes de liderazgo capitalista (Avolio, Walumbwa, \& Weber, 2009) - que los modeliza como productores o consumidores. Veamos pues la vertiente ilocutiva y perlocutiva (Berrendonner, 1987) del sujeto enunciativo denominado Pablo Iglesias (me estoy refiriendo a él como ítem semiótico, como unidad cultural y analítica, obviamente, y no como persona o ciudadano) en su audaz intento de abrochar la enunciación popular con la enunciación mediático-electoral. Ahora, además de audaz, la operación es realmente inédita y en après coup puede ser interpretada como un experimento ejemplar de asalto a los media y al cerco político que estos resguardan.

Por tanto, el primer paso de Pablo Iglesias fue del "No nos representan", no al cerco político, sino al mediático. Es decir, pasa a incrustarse en una de las subespecies del espacio informativo que enmarca al líder político y que en las sociedades neoliberales se reserva como el lugar de eclosión de la confrontación política bajo el semblante de pluralismo. Con lo cual, pasa a hablarle a la gente de perfil, como explicaremos a continuación. Recordemos que en su programa La Tuerka hacía una alocución siempre mirando a cámara, hablando directamente al espectador extradiegético, pero se dio perfecta cuenta de que este formato no era suficiente (Riobóo, 2014). Razones, muchas: la audiencia limitada en stream, claro, pero también que esa puesta en escena populista no modula igual el flujo comunicativo si se hace desde el poder -como Hugo Chávez- que si se hace connotando marginalidad, cosa a la que contribuía el decorado estilo "radio pirata" de La Tuerka. No se trataba de hablar o arengar, se trataba de discutir, es decir, de que hubiera una representación palpable (plástica, textual, fijada en un discurso público) de su victoria dialéctica y para ello lo más inteligente era incrustarse en la misma función marco.

Ahora bien, esta entrada en la comunicación como Campo Único de Enunciación, bajo el semblante del pluralismo, no puede dejar de tener efectos secundarios, porque todo canal, toda escena, todo lugar de enunciación tiene leyes de refracción propias. El empeño experimental nos parece audaz y realmente novedoso, no banalmente innovador (en el sentido institucional y domesticado del I+D+i). Para empezar se trata de pasar del laclauismo silvestre al "tecnolaclauismo". No queremos decir que en Latinoamérica no se utilizaran los media para construir hegemonías populares contra el neoliberalismo, claro 
(Elórtegui Gómez, 2013). Estamos diciendo que en un entorno noroccidental de capitalismo avanzado y democracias blindadas, la fabricación técnica del líder y de la hegemonía tiene notas completamente distintas, que llevan a la utilización de técnicas de marketing y construcción viral de las tendencias basadas en el consenso pluralista. Vale decir que nos encontramos en un punto antinómico al pretender construir un antagonismo desde el consenso aprisionado en el dogma de la corrección política, lo que conlleva la necesidad de un sistema de control significante para no herir sensibilidades enquistadas en una determinada sensibilidad política ${ }^{4}$, a la que se quiere atraer.

Porque, lógicamente, este salto, sin aparato, sin control enunciativo centralizado, provoca un comprensible escándalo en las opciones políticas preestablecidas, alineadas con la derecha y la izquierda parlamentarias. Por un lado, Pablo Iglesias esgrime un cierto populismo en sus actos y comparecencias, ahora ya como líder político en activo y no como simple tertuliano. Significantes como "gente decente", o "casta", la huida de la dialéctica de la lucha de clases en la textura de su discurso, el "No somos de izquierdas ni de derechas", provocan un cierto malestar y desconfianza en la izquierda desubicada en sus patrones de decodificación habituales. Sí, porque de repente aparece una voz que no "podemos" encajar en los moldes tradicionales y que se busca por todos los medios acoplar en alguna de las categorías conocidas para poder manejarse con ella. No diríamos que esta es una voz compleja, sino esencialmente transgresiva de los esquemas comunes de encauzamiento de la pulsión en el discurso político. Sin embargo, esta voz, la de los mítines y entrevistas, mantiene una disciplina discursiva férrea, en base a una serie de reglas léxico-discursivas ${ }^{5}$ (orientadas por un objetivo semiótico y estratégico claro: abrochar la enunciación volátil de la calle, del activismo, de los movimientos sociales, con la enunciación mediática y electoral. O con otras palabras, atraer a los votantes tradicionales de la derecha que estaban votando contra sus "intereses objetivos". El caso, es que en cuestión de semanas, allá por enero de 2014, Pablo Iglesias pasó de ser un tertuliano y un influencer a convertirse en una especie de líder natural. Los efectos ideológicos poderosos producen la impresión de estar vehiculando valores que están ahí desde siempre, aunque sean perfectamente historizables.

\subsubsection{Pablo Iglesias en la televisión}

Desde su salto a la política y antes de tener representación en los diversos ámbitos parlamentarios españoles (central o autonómico), la gente se empezó a

${ }^{4}$ En otro lugar, hemos definido estas sensibilidades como "comunidades de goce" (Palao Errando, 2013).

${ }^{5}$ Vid. Podemos (2014a). 
referirse a la enorme presencia de Pablo Iglesias en televisión desde la modalidad enunciativa del escándalo y la sospecha. ¿Por qué le dan pábulo, por qué lo potencian, a quién conviene políticamente que la figura de Pablo Iglesias destaque? ¿Es una estrategia del PP para dividir el voto de la Izquierda? Lo primero que hemos de pensar, si queremos hacerlo con un cierto rigor, es que las empresas mediáticas no obedecen tanto a sus dueños, como a los mercados. La ideología es una cuestión de voz y de lugar en el discurso, no de simple positivismo contenidístico. Como clave hermenéutica, la propiedad de los medios es trivial comparada con el establecimiento de la agenda (McCombs, 2006). Esta es la que tiene un valor enunciativo y discursivo. Controlar qué y cómo se tratan los temas. Y una cadena no puede dejar de sacar a un tema o un personaje, o contraprogramar con otros, si lo hace la competencia. He ahí todo el secreto: Pablo Iglesias es audiencia.

Ahora, no todo acaba en esa banalidad, también es importante ver cómo está estructurado el sistema mediático español y los efectos que ello pueda tener. Para lo que nos compete, baste decir que hay tres grandes grupos televisivos en España (Bustamante, 2013). Uno, público: RTVE. Dos, privados: Atresmedia y Mediaset (García-Santamaría, Pérez Serrano, \& Alcolea Díaz, 2014; García-Santamaría, 2013). A su vez, los tres grupos tienen un canal principal (TVE1, Antena 3 y Tele 5) otro, secundario (La 2, La Sexta y Cuatro) y otros varios satélites, normalmente con una especialización temática. Las cadenas serias e importantes para los grupos mediáticos son sus buques insignias: aquellas cuyos "telediarios" compiten por las máximas audiencias. En ese sentido, los de Cuatro o La Sexta son relativamente secundarios para sus empresas. Lo mismo, la estructura de la programación. La 1, Tele 5 y Antena 3 cuentan con potentes magazines matutinos, con una tertulia a primera hora. Lo que transmiten es, pues, una sensación a la audiencia de que son el contacto privilegiado con la realidad. Mientras, las cadenas secundarias están especializadas en formatos genéricos: deportes, series de mediana o mayor audiencia, tertulias políticas... La Sexta o Cuatro no tocan la política "seriamente" sino como un formato de infoentretenimiento (Casero Ripollés \& Marzal Felici, 2011; Thussu, 2007) al que concurren periodistas y, sobre todo, políticos de segunda fila (es decir, no destinados, al menos a corto plazo, al poder ejecutivo) como tertulianos. Otra cosa es que, por efecto de esta notoriedad, algunos tertulianos puedan acabar como candidatos a puestos ejecutivos como el caso de Antonio Carmona (PSOE) u otros. Por eso es interesante observar algunos rasgos de puesta en escena que van variando en las apariciones de Pablo Iglesias desde que dio el salto al terreno electoral. De hecho, cuando volvió a La Sexta Noche, programa en el que había sido participante habitual antes de las Elecciones 
Europeas y de la formación de Podemos el 4 de octubre de 2014 (http://goo. gl/362Fna), ya no como tertuliano, sino como líder político en activo con aspiraciones ejecutivas, el tema fue tratado abiertamente por el conductor del programa: le preguntó cómo había de tratarlo a partir de este momento, si volvería como tertuliano, etc. Pero en definitiva, lo más importante son los tratamientos en el encuadre y respecto a la ubicación y temporalidad. La última vez que recordamos (no hemos contrastado el dato, pero nos parece lo más verosímil) haber visto a Pablo Iglesias en Cuatro, actuando como personaje televisivo y prácticamente como miembro de la plantilla es en una parodia del mensaje navideño del rey en diciembre de 2013 (https://goo.gl/Wjx duu), en la que pedía abiertamente la instauración de la República. El vídeo es importante, porque leído retrospectivamente puede pensarse como la despedida de un rol y el acceso a otro.

En definitiva, independientemente del contenido semántico que puedan vehicular sus enunciados verbales y determinados gestos puntuales, Pablo Iglesias ha acabado por respetar escrupulosamente el statu quo enunciativo del líder político, aún más desde que ha accedido a su acta de diputado, al menos en tanto se dirige a los medios generalistas.

\section{2. El tablero, la agenda y las operaciones de reflotamiento}

\subsubsection{El bipartidismo aumentado}

Tras su paso a la política activa, pues, la puesta en escena del actor político Pablo Iglesias fue cambiando gradualmente de tertuliano a entrevistado. Desde entonces, la mayor parte de las veces es entrevistado en directo fuera del plató y, por supuesto, comenzaron a emerger los colaboradores que se pueden batir en las tertulias evitando desgastar la imagen del líder. No es pues solo una cuestión de audiencias o números, sino de estructura del sistema comunicativo y de posición enunciativa. Pablo Iglesias ha ido adoptando poco a poco la posición del líder mediático serio, sin abandonar su vestuario ni su coleta. Pero una dirección de la mirada y un recorte en el encuadre apropiado valen más que mil mediciones del espacio en la pantalla o del tiempo concedido.

El caso es que el sistema ha reaccionado y el asalto al bipartidismo y a la llamada centralidad del tablero (Podemos, 2014b) por parte de Podemos ha sido compensado por el sistema mediático y político por medio de lo que podríamos llamar un bipartidismo aumentado, con la puesta en juego estatal de una opción política catalana como Ciudadanos cuyo ideario españolista lo ha traído a la primera línea de la política en todo el Estado, convirtiéndose en un neutralizador de Podemos como representante exclusivo de la nueva política. Esta, 
ahora, contraviniendo toda la estrategia antagonista de Podemos, vuelve a tener una versión de izquierdas y otra de derechas. Para intentar evitar esta visión de las cosas, de hecho, Pablo Iglesias eludió durante casi todo el año 2015 cualquier enfrentamiento directo con Albert Rivera, el líder de Ciudadanos. Pero unos resultados muy inferiores a los que pudieron llegar a esperarse en las elecciones autonómicas, municipales, andaluzas y catalanas, así como una caída continua en las encuestas a lo largo de $2015^{6}$, acabó obligándolo a aceptar un debate a dos bandas. Es decir, que la agenda informativa, cuya conquista e influencia en su establecimiento era uno de los objetivos estratégicos esenciales de Podemos, ha acabado imponiendo sus condiciones y ha obligado al Pablo Iglesias post-tertuliano a volver al debate televisivo, si bien ahora en un formato híbrido entre el talk show y el debate entre políticos profesionales.

No tenemos aquí espacio para un análisis minucioso, pero en efecto, el formato del debate es curioso. Emitido el 16 de octubre de 2015, en el seno de Salvados, programa de la estrella de La Sexta dirigido y presentado por Jordi Évole, se desarrolla en el bar Tío Cuco del Barrio de Canyelles en Barcelona en un tono entre la conversación de bar y el debate político. Pero lo que es obvio, es que supone una asimilación discursiva que Pablo Iglesias hubiera querido evitar a toda costa: de la "nueva política" se ha pasado a hablar de los "nuevos políticos". Es decir, el desbordamiento se ha convertido en simple novedad.

No es cuestión aquí de entrar en los contenidos políticos (vale decir, programáticos) del debate, ni en quién venció, pues son elementos banales si no tenemos en cuenta, sobre todo, la modulación discursiva que enclaustra todos estos contenidos en la trivialidad de lo novedoso: dos candidatos jóvenes -uno liberal y el otro "progresista"- que vienen a darle aire fresco a la política española. La puesta en escena no deja lugar a dudas. Vemos una avenida a través de la ventanilla trasera de un vehículo. Por zoom out pasamos al interior del vehículo, en cuya parte de atrás viaja Rivera con el asiento de al lado libre. Recogen de la calle a Iglesias y todo el preámbulo va alternando planos de situación Barrio de Canyelles, declaraciones de los vecinos y secuencias de ellos dos hablando como colegas de sus problemas laborales y personales como políticos profesionales. Es decir, la asimilación profesional de sus figuras confina toda diferencia al lado más banal, de oferta programática de la política, excluyendo "lo político" (Marchart, 2009) del tapete. Cuando finalmente se encuentran con Évole, lo primero es incidir en la épica televisiva con cierto autobombo, recordar el debate Aznar / González de 1993. Lo fundamental es que están

\footnotetext{
${ }^{6}$ Vid. esta evolución, por ejemplo, a través de los sondeos de Metroscopia, http://elpais. com/tag/metroscopia/a/.
} 
haciendo historia de la televisión política. Y que están renovando -no, "desbordando"- el bipartidismo. Posteriormente se dirigen a un kiosco y Évole repara en una portada que El País le dedica a Ciudadanos. Pregunta a Rivera si no los está tratando "muy" bien. Rivera contesta que lo mismo hizo con Podemos cuando era novedad. Comienza el debate, perfectamente confinado en un formato televisivo y en la agenda. Creemos que esto es lo más relevante: la nueva política ha acabado consistiendo en una mera cuestión generacional. Nada más.

\subsubsection{Significantes flotantes y significantes vacíos}

En esta tarea de indagar cómo Podemos negocia con la agenda y el sistema comunicativo, es importante que retomemos algunos términos de Laclau que nos pueden ser muy útiles en nuestro análisis. Ya hemos visto cómo Laclau y Mouffe realizan un trabajo de acercamiento de la estrategia socialista al campo de la hegemonía. Y lo hacen a través de una serie de términos provenientes de las ciencias del lenguaje que devienen esenciales para el análisis político postmarxista (Ernesto Laclau, 1993). Puede que la noción de significante vacío, que permite iniciar una cadena equivalencial que articule una posición hegemónica, sea el más relevante de ellos:

¿Qué sería un significante vacío en el sentido más literal del término? Sería un significante al cual no le correspondería ningún significado. Pero un significante sin relación con el proceso de significación, no pertenecería en absoluto al orden significante, sería simplemente una secuencia de sonidos. De modo que si tenemos algo que podemos llamar un significante vacío, deberemos descubrir otra cosa: de qué modo dentro del proceso mismo de la significación, un vacío -que es inherente al acto significante mismo-, puede llegar a ser positivo. Y en ese sentido, el significante vacío es el significante de la vacuidad, no es un significante que carezca de relación con el proceso de significación. (...) La representación de este momento totalizante sólo es posible si un cierto objeto, si una cierta particularidad asume la representación de una totalidad que es completamente inconmensurable respecto a sí misma. Este tipo de relación -por la cual la particularidad asume una función universal de representaciónes exactamente lo que yo llamo la relación hegemónica. Hay hegemonía siempre que se da esta negociación -en última instancia imposible- entre lo particular y lo universal. Para darles un ejemplo concreto, en el caso de "Solidaridad" en Polonia, las demandas de los obreros de Gdansk eran al principio demandas particulares de un grupo de personas en una cierta localidad. Pero al darse esas demandas dentro de un clima general represivo -en el que todas las otras demandas eran negadas- esas demandas particulares asumieron una representación simbólica de carácter más general. Y en eso es en lo que consiste exactamente el proceso hegemónico (Alemán \& Laclau, 2003) 
Es importante, pues, traer desde ahora la diferencia esencial, entre significantes vacíos y significantes flotantes. Como aclara el propio Laclau:

$\mathrm{Y}$, por las razones antes mencionadas, cuanto más extendida la cadena tanto más ese nombrar habrá de prevalecer sobre las referencias particularísticas de los eslabones individuales. Es por esta razón que hemos hablado de destrucción del sentido a través de su misma proliferación. Esto hace posible entender la relación precisa entre significantes "vacíos" y "flotantes": dos términos que han tenido una circulación considerable en la literatura semiótica y postestructuralista contemporánea. En el caso del significante flotante, tendríamos aparentemente un exceso de sentido, mientras que el significante vacío sería, por el contrario, un significante sin significado. Pero si analizamos el problema con más atención, veremos que el carácter flotante de un significante es la única forma fenoménica de su vacuidad. Un significante como "democracia" es, ciertamente, flotante; su sentido será diferente en los discursos liberales, radicales antifascistas o conservadores anticomunistas (Ernesto Laclau, 2014: 31)

¿Cuál ha sido pues la implementación estratégica por parte de Podemos del cálculo significante laclauiano? La parte de la retórica verbal es conocida (Podemos, 2014a). El uso de significantes como "casta" o "gente decente" que desplacen el enfrentamiento liberal-parlamentario clásico entre izquierda y derecha, o el planteamiento marxista de la lucha de clases a un eje "los de arriba" vs. "los de abajo". En fin, no se trata más que de recoger y sistematizar hacia una fase instituyente la construcción de un antagonismo cuyas bases ya estaban en el 15M con el fin de generar una "máquina de guerra electoral" en el marco de la guerra de posiciones gramsciana. Íñigo Errejón (Errejón Galván, 2014), máximo responsable de la estrategia electoral de Podemos, ha sido siempre muy claro al respecto. Ahora bien, el problema que aquí nos planteamos es otro, porque evidentemente la lógica significante no se juega en abstracto, sino que se juega en un campo enunciativo concreto. En la época de la globalización podríamos decir que se trata de la comunicación como campo único de enunciación (García Catalán, 2012; Palao Errando \& García Catalán, 2011). Es en este entorno donde se entabla la batalla por el "sentido común" y "la centralidad del tablero" (Errejón Galván, 2014; Podemos, 2014c).

\subsubsection{Significantes audiovisuales y significantes flotantes}

Por lo tanto, lo que se puede hacer en una operación de conquista hegemónica no es tanto conseguir performativamente el vaciamiento de un significante, como ser capaz de detectarlo. Porque, efectivamente, para ser capaz de "vaciar" un significante necesitaríamos un metalenguaje completo que permitiera una 
consistencia tal que lo hiciera pre-decible. Es decir, volveríamos a caer en una ontología esencialista que proscribiría la contingencia hegemónica. Por lo tanto, como estrategia incoativa, lo más que se puede hacer en este juego por ganar la famosa "centralidad del tablero" es intentar introducir en la agenda mediática (McCombs, 2006) (que también puede ser denominada, según el contexto, sentido común, por ejemplo) una serie de campos semánticos que desplacen a los anteriores y a la representación de la realidad que "vehiculaban". Es el modo de proceder de la "corrección política", de las estrategias de visibilización, etc., de muchas luchas sectoriales (feministas, LGBT, raciales, de los discapacitados, etc.) y siempre incluye una antinomia: saberse minoría y exigir como un derecho ser reconocidos por la mayoría y que sea incluida su diferencia en el todo social bajo especie de derecho. Ahora bien, esta estrategia sectorial -demanda democrática- cuando intenta implementarse en la lucha hegemónica -convertirse en demanda popular-incurre en una cierta antinomia: creerse mayoría (o al menos, tener derecho a ser representante del todo) pero saberse minoría. Porque, y es la gran baza ganadora del poder en las democracias emplazadas (Vattimo \& Zabala, 2012), todo oprimido en un sistema regido por el parlamentarismo representativo debe sentirse minoritario. Cualquier antagonismo implica, pues, de entrada, variar este sentimiento, esta autorepresentación.

Así, la trayectoria sociopolítica que va del 15M hasta la emergencia electoral de Podemos, desplaza las clásicas antinomias parlamentarias e ideológicas derecha/izquierda, explotadores/explotados (la lucha de clases) o centro/periferia hacia otras como casta/gente decente, los de abajo/los de arriba. Y, siguiendo directrices más negrianas (Hardt \& Negri, 2011) que laclauianas, empieza a hablar de lo común como tercer elemento que desplace la dicotomía público/privado.

El problema es que la modelización (Lotman, 1996) excede lo semántico. Operar sobre los campos léxicos, -como operar sobre la ética discursiva habermasiana (Palao Errando \& García Catalán, 2011; Palao Errando, 2001), por ejemplo- olvidando la forma significante y las prerrogativas del dispositivo, es ponerse a merced del sistema, es decir, de cualquier replicante interlocutivo. O, dicho con otras palabras, que el tablero está signado por lógicas semióticas y discursivas inconsistentes lógicamente -el inevitable punto de distorsión de toda ideología (Emesto Laclau, 2014)- que no son controlables metalingüísticamente a priori. Esto es, que cualquier significante introducido en el tablero puede ser rápidamente "flotabilizado", distorsionando modalmente su campo semántico. La ideología no es cuestión solo de semántica, sino de jerarquía de los enunciados. Las ficciones verdaderas inciden sobre la realidad, son un tránsito hacia ella; los simulacros son representaciones que se cierran 
en sí mismas dando al sujeto la falsa impresión de sentirse a salvo, como la novela realista, el teatro burgués, la televisión y el cine de Hollywood. Probablemente, la cuestión no debió ser nunca llegar a las tertulias para ganarlas. Como nunca debió serlo ganar la centralidad del tablero, sino promover que la partida se jugara en otro sitio.

Todo lo antedicho quedaría como mera abstracción teórica si no somos capaces de mostrarlo en un -mínimo, por imperativo de espacio- ejercicio analítico. Veamos pues, siquiera sea sumariamente, cómo la lógica significante audiovisual puede modular la semántica hasta alejar el sentido definitivamente del imaginario (mítico) significado original. Nada mejor para ello que asomarnos a algunos de los spots de las diversas candidaturas para las Elecciones Autonómicas y Municipales de 2015. Por ello, creemos que lo mejor es proceder viendo cómo son utilizados algunos campos semánticos puestos en liza primero por el $15 \mathrm{M}$ y después por Podemos, como son la temática de "lo común" y de la traición histórica del orden constitucional al pueblo español, y examinar su proceso de "flotabilización", es decir, de desactivación de su potencial equivalencial emancipador y su apropiación por las fuerzas políticas que más interés tienen en desactivar ese antagonismo, operación que se lleva a cabo a través de los recursos propios del discurso audiovisual.

El run-rún (@ivanlagarto, 2015)

Si el gesto semántico (Mukarovsky, 2000; Palao Errando, 2009) es el que promovió el 15M, de todos los spots que hemos podido visionar, este es con diferencia el que le es más poética, formal, creativamente, fiel con diferencia. Primero, desde sus marcas enunciativas. Para empezar, el run-rún ya connota multitud, voz no unificada ni monopolizada. Para seguir, su autor es @ivan lagarto, una figura de las redes y no un profesional de la comunicación política institucional (en difusión). Por eso, su estética, su montaje, es la del meme y el collage, no la del montaje ficcional. Lo que unifica todo el spot es la voz de Ada Colau, que unas veces aparece diegetizada (sincronizada con la imagen) y otras superponiéndose a los planos. En fin, toda la puesta en escena connota la oposición de la gente común a cualquier tipo de élite a través de la alegría, de la negación de la profesionalidad -es decir, de la posición de explotado servicial, entusiasta y eficiente- como rasgo inherente a la política y como vínculo social privilegiado. Por eso, Ada Colau ejerce de lideresa no profesional, ejerce un liderazgo de la multitud que no usurpa su voz: aparece canturreando, no cantando. Y, a su vez, una gran parte del metraje está constituido por esos momentos en los que los actores de una ficción (representación) caen también fuera de su semblante profesional: las llamadas tomas falsas. 
Emplazado el sujeto de la enunciación, las propias opciones estéticas del spot son también absolutamente coherentes con la batalla ideológica que se está librando. Se ha elegido una rumba en castellano, lo cual ya es una declaración de intenciones en Cataluña que distancia la opción de Barcelona en Comú del espectro estrictamente soberanista. Eso sí, cuidando de incluir (invitar) los símbolos nacionalistas como parte de una propuesta más amplia, que se le ofrece como marco, en el metraje documental añadido. Y, lo más fundamental, excepto los planos del estudio, todos los planos nos muestran espacios urbanos populares y abiertos, gente relacionándose en los espacios comunes de la ciudadanía. En fin, el plano final de Ada Colau, mirando al centro axial de la cámara (a los ojos del espectador) pero en silencio, buscando una complicidad que deniegue cualquier usurpación de la voz del espectador, es toda una declaración de intenciones.

\section{PSOE \#GobernarParaLaMayoría (PSOE, 2015)}

Si hemos elegido este spot para contraponerlo al anterior es porque probablemente sea el caso más astutamente sutil de flotabilización de los significantes que nos hemos encontrado. Aquí el idiolecto estético (Eco, 1986) es justamente todo lo contrario del anterior: todo indica profesionalidad, en la enunciación y en el enunciado. Tenemos una voz en off heterodigética y un ciclo ficcional perfectamente pautado que va de la mañana a la noche. Nada de liderar un movimiento popular, sino de ofrecerse "profesionalmente" ${ }^{\text {" }}$ para satisfacer las demandas del ciudadano-consumidor. Por supuesto, una idea base del movimiento neo-constituyente del 15M es que la gente decente ha cumplido con sus obligaciones y ha sido traicionada por la casta corrupta. Pero aquí, la gente se ha convertido en mayoría: en mayoría designada por su desempeño laboral y económico, profesional.

Veamos. Para empezar y como primer gran contraste con el anterior, todos los espacios que aparecen en este spot son cerrados: viviendas, comercios, lugares de trabajo. Hasta tal punto, que el pescador que aparece está perfectamente distanciado de la cámara, que en ningún caso comparte espacio con él, sino que se sitúa fuera del barco convirtiéndolo en un espacio enclaustrado. La norma estética (Mukarovsky, 2000; Todorov, 1978) es severa. Pero aún más: si nos fijamos, siempre que se representa un trabajo manual (pescador, mozo de almacén, trabajadores del mercado) se ofrece desde una mirada superior, en picado (en el caso del pescador, claramente cenital). Es una mirada estadísti-

${ }^{7}$ Para una recensión de la figura del profesional en el tardocapitalismo vid. (Palao Errando, 2004) 
ca, estatal, que no invita en absoluto a la identificación entre el sujeto de la enunciación y el sujeto del enunciado. Además, sutilmente, en el ciclo diario que se nos ofrece se produce una progresión narrativa de ascenso social. Comenzamos con una familia de trabajadores (veladamente, de parados) que son ofrecidos con una estética de serie española retro (el grano, el mobiliario o el vestuario sería perfectamente congruente con series actualmente en emisión como Cuéntame de RTVE o Amar es para siempre de Antena 3). Luego pasamos a la familia de clase media baja (padre autónomo que trabaja en casa -la impresora y la mesa de despacho así lo indican- pero que no puede emplear a su hija) con una estética de sitcom también a la española. Pero cuando llegamos a los profesionales liberales, la estética ha pasado a ser más bien de serie americana: establishing shot nocturno de edificios con ventanas iluminadas -así trabajan todos los policías y abogados de las series americanas- que culmina con el padre profesional llegando tarde a casa -los niños van en pijama, no perdamos el detalle-. Todo acaba con una escena hogareña, también precedida de un establishing shot interno, final también típico de las series USA.

En resumidas cuentas, se ha reflotado todo el espectro semántico del 15M, del desbordamiento, de la crisis representativa y se ha llevado a un campo enunciativo liberal/socialdemócrata, restándole todo componente populista. El tablero ha devuelto su centralidad (enunciativa) al centro (político), llevando de la mano al espectador en el interior de la fábula (Eco, 1981).

\section{Otros spots}

Simplemente, con estos dos muy sucintos ejercicios de análisis es muy fácil ver cómo han procedido otras fuerzas políticas (vid. Videografía). De la denegación del Partido Popular (Partido Popular, 2015) (el sentido común es el nuestro y todo lo demás son rarezas irresponsables), a la absorción en el espectro ejecutivo empresarial de la semántica del desbordamiento, con el líder mediático Albert Rivera paseando su apostura por los no lugares de los que hablara Marc Augé, a lánguida cámara lenta para acabar entre vítores (Ciudadanos, 2015).

¿Y Podemos, la que debería haber sido la principal fuerza del desbordamiento en estas elecciones y haber liderado el proceso? Pues su discurso ha sido penosamente reabsorbido en el discurso sistémico por vía escenográfica y ha sido desactivado su potencial antagónico y subversivo. En el spot de inicio de campaña (Podemos, 2015) tenemos una apuesta tibia y mediocre, utilizando imágenes genéricas, de tipo clase media y sin ningún tipo de innovación visual ${ }^{8}$,

${ }^{8}$ Pueden compararse los dos spots de Podemos con el de Izquierda Unida, que acomete una clara acrobacia visual (Izquierda Unida, 2015). 
y en el de final la típica de la política profesional: el mitin (Podem Comunitat Valenciana, 2015). El discurso de Podemos ha quedado centrado y la impresión es la que pretendían las fuerzas rivales: la reabsorción formal del campo semántico del desbordamiento lleva a dar la impresión de que al final Podemos está diciendo lo que todos... Son las reglas enunciativas del tablero, más imperativas cuanto más centrales...

\section{CONCLUSIONES: LA OPERACIÓN PODEMOS Y EL RIESGO DE LA TELECRACIA}

La televisión consiguió hace mucho tiempo posicionarse hegemónicamente en el panorama mediático porque logró hacerse con el papel de ágora global y convertirse en nuestro patrón y principal contacto con la realidad, con lo que no vemos. Primero, le robó ese espacio al cine, en una operación parangonable a la que había realizado la fotografía respecto a la pintura en perspectiva en el siglo XIX, usurpando la representación de la realidad. Después, pese a los embates de los medios digitales ha conseguido conservar ese papel. Nada es susceptible de entrar en el régimen de la verdad hasta que no pasa al ágora. El principal problema enunciativo de la política actual es precisamente que está atrapado en la comunicación como campo único de enunciación y ello supone que estamos completamente modelizados por el patrón televisivo y por los géneros del infotainment (Thussu, 2007) en los que se ha conseguido encarcelar cualquier voz popular en un pluralismo espectacular dirigido al goce público.

De tal modo, una de las grandes armas en este falso dialogismo, al estilo de la pseudo-oratoria del talkshow y la tertulia, consiste en atribuir toda voz opuesta a un locus de enunciación prejuzgado. Confinar la voz del oponente, para aislar sus argumentos de toda posible interactuación discursiva, acaba enajenando cualquier debate del campo de la verdad (Palao Errando \& García Catalán, 2011), porque si todo oponente discursivo se convierte en un enemigo cuyo discurso es ya conocido y repudiado desde un siempre mítico (Palao Errando, 2013), es imposible que el debate pueda designar nuestra posición subjetiva, esto es, que podamos descubrir cualquier error en nuestros automatismos mentales. Éste es el poder hipnótico del pluralismo espectacular y polémico, que no agonístico. El clientelismo a que nos sometió el bipartidismo nos hace ser incapaces de ver la contingencia, la inconsistencia de un pensamiento y una línea política en formación, en contradicción, rica y poliédrica en sus facetas y en sus fisuras. La aldea global no trae una nueva transparencia, sino un panorama epistémicamente complejo, aunque tal vez menos limitado para la acción, y también menos mensurable métricamente que el panorama del broadcasting y de las viejas industrias culturales. Tal vez, mejor caldo de cultivo para el surgimiento de lo nuevo. 
Podemos, de momento, se ha constituido sobre la idea de dar una sola voz a las voces múltiples, de llevar las demandas de la calle al interior del sistema. Estamos en condiciones afirmar, pues, que si Podemos ha traído una transformación estructural de hondo calado en el sistema político español, también ha significado, y tal vez antes que nada, una auténtica revolución comunicativa. No solo a través de los social media (Facebook (Sampietro \& Valera, 2015) y Twitter fundamentalmente), sino a través de los interminables hilos de discusión en la plataforma Reddit Plaza Podemos (http://goo.gl/9HU2hy), chats de Telegram, etc. Y sobre todo las plazas, los barrios, las calles, los jardines, los solares, redes ubicuas, medios locativos, conversaciones.

La cuestión es, pues, que tras el impulso de las europeas hubo en Podemos un proceso de escisión interna entre dos planteamientos: aquellos que veían, en torno al liderazgo de Pablo Iglesias y del núcleo promotor, esencialmente una máquina de guerra electoral (Errejón Galván, 2014), frente a los que lo concebían de un modo asambleario y horizontal, donde las decisiones partirían de abajo hacia arriba concediendo a los círculos el papel de fuente principal de la iniciativa política. El caso es que el triunfo de las tesis de Pablo Iglesias (Podemos, 2014) en la Asamblea Ciudadana de octubre de 2014 consagra un modelo contrario. Se está produciendo, pues, un fenómeno curioso: si bien, la gente puede intervenir en Podemos telemáticamente a través de Poemos.info, Plaza Podemos y por supuesto, en las votaciones a través de la plataforma Agora Voting, ello implica que el sistema tiene una propensión de base que podríamos llamar telecrática (Stiegler, 2006). El núcleo promotor tiene acceso a las televisiones, y otros muchos miembros del Consejo Ciudadano a medios escritos, mientras que las tesis que se les oponen tienen ese recurso muy limitado. La conclusión es que, con la posibilidad de confeccionar listas completas para todos los puestos de cada órgano, y de elegirlas con un solo click, las listas -y las tesis- patrocinadas por Pablo Iglesias bajo la marca Claro que Podemos ganan regularmente de una forma aplastante. Los que votan, pues, son los televidentes convertidos en televotantes.

En consecuencia, consideramos como una labor perentoria, y para que la que aquí no tenemos espacio, un análisis semiótico, retórico y plástico (Campanelli, 2010; Català Doménech, 2010; Lister, Dovey, Giddings, Kelly, \& Grant, 2009; Verhoeff, 2012) tanto de las interfaces web como de las interfaces ubicuas (Dovey \& Fleuriot, 2011; Ekman \& Fuller, 2013), además de su enfoque algorítmico (Gillespie, 2012; Introna, 2013), también muy necesario para entender esta "broadcastización" de los medios digitales vocacionalmente reticulares, y dilucidar así el alcance de esta prevalencia de la difusión telecrática en un entorno de caos reticular que conculca la claridad connotada por las candidaturas oficialistas de Podemos. 
El caso es que la complejidad enunciativa está claramente relacionada con la noción de locus enunciationis (las modalidades enunciativas de Foucault (2002)) abundantemente usada, sobre todo, por los llamados estudios postcoloniales. Porque, claro, el lugar desde el que se enuncia modeliza el lugar de la recepción y modeliza el canal. Como hemos visto, el líder político mediático se dirige a la opinión pública en la esfera pública y esta opinión pública queda definitivamente emplazada como un sujeto pasivo e irresponsable. La construcción de la opinión pública como enunciatario puede ser leída, pues, como un intento de llevar la comunicación al Modelo Difusión, a una voz lo menos plural e interactiva posible, es decir, reconducir una posible voz popular, que se antoja demasiado anárquica, al orden cuantificable y doméstico del electorado eufóricamente pasivo. Es la diferencia entre el potencial subversivo de la hermenéutica y el potencial de reordenación de la comunicación política. Ello es correlativo a la búsqueda de indicadores cuantitativos, con intención de reducir toda la complejidad de las voces enunciativas a la "claridad" de los datos y las encuestas, esto es, del frame preestablecido. Y ello lleva a las fuerzas políticas, necesariamente, a convertirse en esclavas de los sondeos. De hecho, todo método es también un locus enunciationis, porque al diseñar sus objetivos modeliza indefectiblemente sus resultados. Los datos son mucho más fáciles de manipular que los argumentos.

Evidentemente, semiólogos, comunicólogos y especialistas en el análisis cultural estamos investigando estas cosas y se han dado muchos pasos en la dirección de la comprensión de la cultura digital y del Modelo Reticular. Pero no creo que ningún colega me niegue que, a diferencia de lo que hemos conseguido con las producciones textuales clásicas, sea cual sea su complejidad, que es ser capaces de explicar cómo la forma contribuye y determina la generación del sentido y orienta indeleblemente la interpretación global del texto tanto en lo estético como en lo ideológico, ése es un trabajo que está todavía por hacer en los medios interactivos reticulares. Vamos cerniendo su estructura, sus propiedades gramaticales, su potencialidad, o siendo capaces de medir su influencia y su alcance. Pero aún no hemos dado con la manera de religar todo eso con una semiótica interpretativa de los enunciados que realmente vinculan. Ideológica, sémicamente, las redes son un caos.

Ello no quita que el problema de una ciencia política sin atención a los media es que acaba siendo algo así como ponerse a jugar ignorando a la banca, que es quien reparte las cartas y estructura finalmente la partida. La retórica general de Laclau es una gran herramienta, pero sin tener en cuenta los procesos semióticos, textuales y mediáticos en los que esta batería de recursos deviene enunciado material y concreto puede poner a los científicos políticos 
a revisar continuamente sus ecuaciones a ver qué ha fallado. $\mathrm{O}$ a interpretar como excrementos de paloma el fondo de radiación de microondas que generó el Big Bang, por intentar aprender la lección de un notable episodio de la Historia de la Física.

\section{VIDEOGRAFÍA}

@ivanlagarto. (2015). EL RUN RUN - Ada Colau - AUTOTUNE by @ivanlagarto. https:/ /www.youtube.com/watch?v=wB6NDWKDyKg (visionado el 29 de marzo de 2016)

Ciudadanos. (2015). C's - España pide cambio \#ElCambioCs - YouTube. https://www. youtube.com/watch?v=qOSLKmNFIAk (visionado el 29 de marzo de 2016).

Izquierda Unida. (2015). "Con la razón y con el corazón" Spot de IU Municipales y Autonómicas 2015 \#EsTiempoDeIzquierda. https://www.youtube.com/watch?v= LFafXtcZqR4\&spfreload=10 (visionado el 29 de marzo de 2016).

Pablo Igesias. Mensaje navideño de Pablo Iglesias, futuro presidente de la $3^{\text {a }}$ Republika. https://goo.gl/Wjxduu (visionado el 29 de marzo de 2016).

Partido Popular. (2015). Revolución. Partido Popular Vídeo Campaña Elecciones Locales y Autonómicas 2015. https://www.youtube.com/watch?v=R4CdHbBhb8k \&spfreload=10 (visionado el 29 de marzo de 2016).

Podem Comunitat Valenciana. (2015). Este 24 de Mayo: Podemos! https://www.you tube.com/watch? $\mathrm{v}=\mathrm{CPqZCLOFm} 18 \&$ feature=youtu.be (visionado el 29 de marzo de 2016).

Podemos. (2015). Spot Podemos 24M. https://www.youtube.com/watch?v=fm2s EunsVy8

PSOE. (2015). Spot PSOE Elecciones 2015 La mayoría - \#GobernarParaLaMayoría. from https://www.youtube.com/watch? $\mathrm{v}=$ nuBd7DWnhYg\&feature=youtu.be (visionado el 29 de marzo de 2016).

Salvados. Cara a cara entre Albert Rivera y Pablo Iglesias. La Sexta. Emitido el 16 de octubre de 2015. http://goo.gl/PCeV2X (visionado el 29 de marzo de 2016)

Toret, J. (2014). Comunicación y poder: la tecnopolítica en el 15M. https://goo.gl/e OSUcb (visionado el 29 de marzo de 2016).

\section{BIBLIOGRAFÍA}

Alejandro, R. (2013). Hermenéutica, ciudadanía y esfera pública. Barcelona: Editorial Bellaterra.

Alemán, J., \& Laclau, E. (2003). “¿Por qué los significantes vacíos son importantes para la política?” Mesa Redonda en la EOL - 22/07/03 [*] Jorge Alemán, Ernesto Laclau. http://wapol.org/fr/las_escuelas/TemplateArticulo.asp?intTipoPagina=4\&intEdicion $=1$ \&intIdiomaPublicacion $=5$ \& intArticulo=303\&intIdiomaArticulo=1 \&intPublica cion=4 (consultado el 29 de marzo de 2016)

Avolio, B. J., Walumbwa, F. O., \& Weber, T. J. (2009). "Leadership: current theories, research, and future directions". Annual Review of Psychology, 60, 421-49. doi: 10.1146/annurev.psych.60.110707.163621 
Berrendonner, A. (1987). Elementos de Pragmática Lingüística. Buenos Aires: Gedisa. Bolter, J. D., Grusin, R., \& Grusin, R. A. (1999). Remediation: understanding new media. Choice Reviews Online (Vol. 36). Cambridge, Mass. : MIT Press. doi:10.5860/CHOI CE.36-4895

Buen Abad Domínguez, F. (2012). La guerra simbólica: Hacia una semiótica para la emancipación. Barcelona: Ediciones Bellaterra.

Bustamante, E. (2013). Historia de la Radio y la Televisión en España: Una asignatura pendiente de la democracia. Barcelona: Gedisa.

Campanelli, V. (2010). Web Aesthetics: How digital media affect Culture and Society. Rotterdam: Nai Publishers. Institute of Network Cultures.

Casero Ripollés, A. (Ed.). (2014). Dossier: Democracia y nuevos medios digitales. Telos, 98.

Casero Ripollés, A., \& Marzal Felici, J. J. (2011). Periodismo en televisión : nuevos horizontes, nuevas tendencias. Sevilla : Comunicación social.

Català Doménech, J. M. (2010). La imagen interfaz. Bilbao: Universidad del País Vasco.

Domínguez, A., \& Giménez, L. (2014). Claro que Podemos: de La Tuerka a la esperanza del cambio en España. Barcelona: Los libros del lince.

Dovey, J., \& Fleuriot, D. C. (2011). La estética de los medios omnipresentes. adComunica. Revista de Estrategias, Tendencias e Innovación en Comunicación, 2, 63-80.

Eco, U. (1981). Lector in fabula. La cooperación interpretativa en el texto narrativo. Barcelona : Lumen.

Eco, U. (1986). La estructura ausente. Barcelona: Lumen.

Ekman, U., \& Fuller, M. (2013). Throughout : art and culture emerging with ubiquitous computing. Cambridge, MA : MIT Press.

Elórtegui Gómez, C. (2013). Populismo y comunicación : la política del malestar en el contexto latinoamericano. Barcelona: UOC.

Errejón Galván, I. (2014). "PODEMOS como práctica cultural emergente frente al imaginario neoliberal: hegemonía y disidencia". Conversación con Íñigo Errejón Galván. Revista Científica de Información Y Comunicación, 11, 17-46.

Feenstra, R. (2012). Democracia monitorizada en la era de la nueva galaxia mediática: la propuesta de John Keane. Barcelona: Icaria.

Feenstra, R., \& Casero-Ripollés, A. (2014). "Democracy in the digital communication environment : A typology proposal of political monitoring processes. International Journal of Communication, 8, 2448-2468.

Foucault, M. (2002). La arqueología del saber. Buenos Aires: Siglo XXI.

García Catalán, S. (2012). Hipertexto y modelización cinematográfica en la divulgación neurocientífica audiovisual. A propósito de Redes de Eduard Punset. Castellón: Universitat Jaume I. http://hdl.handle.net/10803/96402 (consultado el 29 de marzo de 2016).

García-Santamaría, J. V. (2013). "Televisión y concentración en España: El duopolio de Mediaset y Atresmedia”. Palabra Clave, 16(2), 366-397. 
García-Santamaría, J. V., Pérez Serrano, M., \& Alcolea Díaz, G. (2014). "Las nuevas plataformas televisivas en España y su influencia en el mercado". Revista Latina de Comunicación Social, 69(2014), 390-417. doi:10.4185/RLCS-2014-1017

Gillespie, T. (2012). "The relevance of algorithms", http://www.tarletongillespie.org/ essays/Gillespie\%20-\%20The\%20Relevance\%20of\%20Algorithms.pdf (consultado el 29 de marzo de 2016).

Habermas, J. (1981). Historia y crítica de la opinión pública. Barcelona: Gustavo Gili.

Hardt, M., \& Negri, A. (2011). Commonwealth: el proyecto de una revolución del común. Madrid: Akal.

Introna, L. D. (2013). Algorithms, Performativity and Governability (**** early draft $* * * *)$. En Governing Algorithms: A conference on computation, automation, and control.

Jenkins, H. (2008). Convergence Culture. La cultura de la convergencia de los medios de comunicación. Barcelona: Paidós.

Laclau, E. (1993). Nuevas reflexiones sobre la revolucion de nuestro tiempo. Buenos Aires: Nueva Visión.

Laclau, E. (2006). "Why constructing a people is the main task of radical politics". Critical Inquiry, 32(Summer), 646-680.

Laclau, E. (2007). La razón populista. Buenos Aires: Fondo de Cultura Económica.

Laclau, E. (2014). Los fundamentos retóricos de la sociedad. Buenos Aires: Fondo de Cultura Económica.

Laclau, E., \& Mouffe, C. (1987). Hegemonía y estrategia socialista: hacia una radicalización de la democracia. Madrid: Siglo XXI.

Lister, M., Dovey, J., Giddings, S., Kelly, K., \& Grant, I. (2009). New Media: a critical introduction. Oxon: Routledge.

Lotman, J. (1996). La semiosfera I. Semiotica de la cultura y del texto. Madrid: Cátedra.

Marchart, O. (2009). El Pensamiento Político Posfundacional. La Diferencia Política en Nancy, Lefort, Badiou y Laclau. Buenos Aires: Fondo de Cultura Económica.

Marzal Felici, J. (Ed.). (2015). Las televisiones públicas autonómicas del siglo XXI. Castelló de La Plana, Barcelona, Valencia: Aldea Global.

Marzal Felici, J., Izquierdo Castillo, J., \& Casero-Ripollés, A. (Eds.). (2015). La crisis de la Televisión Pública: El caso de RTVV y los retos de una nueva gobernanza. Castelló de La Plana, Barcelona, Valencia.: Aldea Global.

McCombs, M. (2006). Estableciendo la agenda. El impacto de los medios en la opinión pública y el conocimiento. Barcelona: Paidós.

Micó, J.-L., \& Casero-Ripollés, A. (2013). "Political activism online: organization and media relations in the case of $15 \mathrm{M}$ in Spain". Information, Communication $E$ Society, 17(7), 858-871. doi:10.1080/1369118X.2013.830634

Morell, M. F. (2012). "The Free Culture and 15M movements in Spain: Composition, social networks and synergies. Social Movement Studies, 11(3-4), 386-392. doi: 10.1080/14742837.2012.710323.

Mouffe, C. (1999). El retorno de lo político: Comunidad, ciudadanía, pluralismo, democracia radical. Barcelona: Paidós. 
Mouffe, C. (2007). Prácticas artísticas y democracia agonística. Barcelona: Museu d'Art Contemporani de Barcelona.

Mouffe, C. (2014). Agonística. Pensar el mundo políticamente. Buenos Aires: Fondo de Cultura Económica.

Mukarovsky, J. (2000). Signo, función y valor : estética y semiótica del arte de Jan Mukarovsky. Santafé de Bogotá: Plaza \& Janés.

Palao Errando, J. A. (2001). El psicoanálisis y la teoría consensual de la verdad: programa para un encuentro imposible. Antroposmoderno. http://www.antroposmo derno.com/textos/elpsicoa.shtml (consultado el 29 de marzo de 2016).

Palao Errando, J. A. (2004). La profecía de la imagen-mundo: para una genealogía del Paradigma Informativo. València : IVAC.

Palao Errando, J. A. (2009). A favor de la Interpretación: por una semiótica a la altura de los tiempos. X Congreso Mundial de Semiótica, Sección "El Discurso: Generación y Transmutaciones," (S/N), 1-12. http://www.bocc.ubi.pt/pag/errando-jose-a-favorde-la-interpretacion.pdf (consultado el 29 de marzo de 2016).

Palao Errando, J. A. (2009b). Cuando la televisión lo podía todo: Quien Sabe Donde en la cumbre del Modelo Difusión. Madrid: Biblioteca Nueva.

Palao Errando, J. A. (2013). "Comunidades de goce". En J. A. Palao Errando (Ed.), POLÍTICA ( ) PSICOANÁLISIS CINCO TEXTOS PARA INVENTAR UN VÍNCULO. Santander: Shangrila. http://www.shangrilaediciones.com/Materiales5-PoliticaPsicoanalisis.pdf (consultado 29 de marzo de 2015).

Palao Errando, J. A., \& García Catalán, S. (2011). “¿Política-basura? Modelos de representación en la telebasura y la tertulia política”. BOCC - Biblioteca On-Line de Ciências Da Comunicação. http://goo.gl/tDCgWD (consultado el 29 de marzo de 2016).

Podemos. (2014a). NUEVE CONSEJOS PARA UN DISCURSO DE MAYORÍAS. No1: Acabar con todo tic anticlerical : Podemos. http://www.reddit.com/r/Podemos/com ments/2c8ioe/nueve_consejos_para_un_discurso_de_mayor\%C3\%ADas_n\%C2\%B Al/ (consultado el 29 de marzo de 2016).

Podemos. Principios organizativos (2014b). https://goo.gl/nCZZQg (consultado el 29 de marzo de 2016).

Podemos. Principios Políticos (2014c). http://goo.gl/hGtYF7 (consultado el 29 de marzo de 2016).

Quodlibetat, SuNotísima, Axebra, Monty, A., Toret, J., \& Levi, S. (2012). Tecnopolítica, Internet y R-Evoluciones: sobre la centralidad de las Redes Digitales en el \#15M. Barcelona: Icaria.

Riobóo, E. (2014). La cara oculta de Pablo Iglesias: De Canal 33 a Bruselas. Madrid: ViveLibro.

Rivero, J. (2014). Conversación con Pablo Iglesias. Madrid: Turpial.

Sádaba, I. (2012). "Acción colectiva y movimientos sociales en las redes digitales. Aspectos históricos y metodológicos”. Arbor, 188(756), 781-794. doi:10.3989/arbor. 2012.756 n4011.

Sampedro, V. (2014). El Cuarto Poder en red: por un periodismo (de código) libre. Barcelona: Icaria. 
Sampietro, A., \& Valera. (2015). "Emotional politics on Facebook. An exploratory study of Podemos' discourse during the European election campaign 2014". Recerca. Revista de Pensament i Anàlisi, 17, 61-83.

Stiegler, B. (2006). La télécratie contre la démocratie: lettre ouverte aux représentants politiques. París: Flammarion.

Subirats, J. (2011). Otra sociedad, ¿otra política? Barcelona: Icaria.

Tascón, M., \& Quintana, Y. (2012). Ciberactivismo: Las nuevas revoluciones de las multitudes conectadas. Madrid: Los libros de la catarata.

Thussu, D. K. (2007). News as entertainment: the rise of global infotainment. London: SAGE.

Todorov, T. (1978). Teoría de la literatura de los formalistas rusos. (T. Todorov, Ed.). Mexico: Siglo XXI.

Toret, J., Calleja, A., Miró, Ó. M., Aragón, P., Aguilera, M., \& Lumbreras, A. (2013). Tecnopolítica: la potencia de las multitudes conectadas. El sistema red 15M, un nuevo paradigma de la política distribuida. IN3 Working Paper Series, 178. http://goo.gl/ Irmsaz (consultado el 29 de marzo de 2016).

Tormey, S. (2015a). "Democracy will never be the same again: 21st century protest and the transformation of politics. Recerca. Revista de Pensament i Anàlisi, 17, 107-128.

Tormey, S. (2015b). The End of representative politics. Cambridge: Polity Press.

Vattimo, G., \& Zabala, S. (2012). Y hermenéutico: De Heidegger a Marx. Barcelona: Herder.

Verdú, V. (2001, October 17). "El 15-M es emocional, le falta pensamiento". Entrevista a Zygmut Bauman. El País. Madrid. http://goo.gl/WTHuCD (consultado el 29 de marzo de 2016).

Verhoeff, N. (2012). Mobile Screens: The Visual Regime of Navigation. Amsterdam: Amsterdam Universitiy Press.

Virno, P. (2003). Gramática de la multitud: Para un análisis de las formas de vida contemporáneas. Madrid: Traficantes de sueños.

Zizek, S., \& Horvat, S. (2014). El sur pide la palabra. Barcelona: Los libros del lince.

JOSÉ ANTONIO PALAO ERRANDO (Valencia, 1962) ejerce como Profesor Contratado Doctor en el Departamento de Ciencias de la Comunicación de la Universitat Jaume I de Castelló en los Grados en Periodismo y Publicidad (Teoría de la Imagen), así como en el Máster en Nuevas Tendencias y Procesos de Innovación en Comunicación (Análisis de los Discursos Transmedia). Ha publicado, entre otros, los libros La profecía de la Imagen-Mundo: para una genealogía del Paradigma Informativo (IVAC, Valencia, 2004) y Cuando la televisión lo podía todo: Quien Sabe Donde en la cumbre del Modelo Difusión (Madrid: Biblioteca Nueva, 2009), así como artículos sobre cine, televisión, imagen y comunicación política en las para múltiples revistas y libros colectivos.

Recibido: 02/11/15

Aceptado: 01/06/16 